\title{
Grandparents raising grandchildren a national concern
}

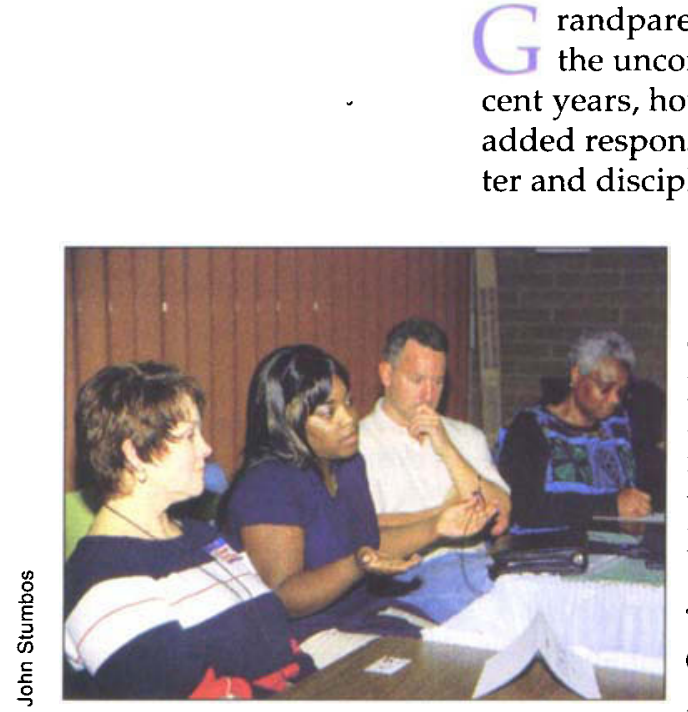

The difficult conditions facing grandparents who raise their grandchildren were discussed at a daylong conference in Sacramento. Panelists included, left to right, Stephanie Zach, Sacramento AARP; Mookie Abdullah, advocate for foster children; Michael Joyce, UC Davis physician; and Mary Blackburn, Alameda County Cooperative Extension. Abdullah lived in 37 different foster homes. battle." ing in poverty.

randparents are universally treasured for the unconditional love they bestow; in recent years, however, many have taken on the added responsibilities of providing food, shelter and discipline for their grandchildren.

There are more than 2.5 million grandparent-headed households in the United States where grandchildren receive the care that the parents can not, for a variety of reasons, offer. At last count, nearly 500,000 California children were living in grandparentheaded households.

"There's a lot of depression. There's a lot of anger," says UC Cooperative Extension (UCCE) Alameda County advisor Mary Blackburn, who has been raising one of her eight grandchildren for the past 9 years. "Some grandparents are on their third group of children. It's a tremendous emotional

The issue of grandparents raising grandchildren - as well as other kin such as aunts, uncles and cousins - has gained wider public acknowledgment, as cities, counties and states grapple with the needs of caregivers who may be themselves elderly, on fixed incomes or liv-

UCCE Alameda County has worked with grandparents who raise grandchildren since the early 1990s, when Oakland became one of the first public agencies in California to respond to the issue. UCCE worked with the city on a demonstration project, then - on its own and without specific programmatic funds - began offering workshops, cosponsoring

\section{Resources for grandparents}

AARP Grandparent Information Center: www.aarp.org/confacts/programs/gic.html

Grand Parent Again:

www.grandparentagain.com

Generations United: www.gu.org

GrandsPlace: www.grandsplace.com

Grandparent Caregiver Law Center: www.brookdale.org/gpc

Senior Legal Hotline Grandparent Project: (916) $551-2140$ or (800) 222-1753 conferences, conducting research and prioritizing needs.

Blackburn utilized U.S. Census data to establish the upward trend in rates of grandparents raising grandchildren in California (see p. 10). "I'm trying to get the facts out there," she says.

An indefatigable advocate for grandparents, Blackburn is providing technical assistance to the California Coalition of Grandpar- ents and Relative Caregivers to establish a nonprofit organization, which could apply for program funding and advocate more effectively.

During a recent UC Division of Agriculture and Natural Resources conference in Riverside, Blackburn noted that "we don't have programs for this group of older parents. You can't talk parenting to a 75-year-old in the same way that you talk to a teen parent."

\section{Upward trend}

As is often the case, California is a bellwether of national trends. According to the 1990 U.S. Census, nearly $5 \%$ of the nation's children were living in grandparent-headed households, compared with $6.4 \%$ in California. In a subsequent 1997 survey, the national rate had risen to $5.5 \%$.

On Feb. 27, the University of Wisconsin's extension service organized a national satellite videoconference, "Grandparents Raising Grandchildren: Legal and Policy Issues," which was beamed down to more than 250 sites including 12 in California.

The Greater Sacramento Grandparent Network and Support Group hosted about 40 service providers and grandparents who are raising grandchildren. The videoconference was co-sponsored by UCCE and about a dozen federal, state, local and independent agencies and organizations.

The 3-hour broadcast included case studies of assistance programs around the nation; discussions about financial, legal and policy issues; information on custody arrangements and visitation rights; and live question-and-answer sessions.

Participants at the Sacramento site raised numerous issues including housing, finances, foster care and education. "We need a one-stop shop for services," said Pearl Bolton, who cares for two grandchildren.

Panelists urged the grandparents to be outspoken advocates for themselves and their grandchildren. "There has to be an articulated, resounding, organized voice," said Sharron Treskunoff Bailey of the U.S. Department of Housing and Urban Development.

\section{Impacts on children}

Blackburn and others are also continuing to focus on how the grandchildren themselves are af- 
fected. About one-quarter of all U.S. children in formal foster care are placed with grandparents or other relatives; many more are placed with strangers or are being cared for by grandparents who have no legal authority.

Mookie Abdullah explained that she entered the system when she was 4 years old, and lived in 37 different foster homes until she was "emancipated" at age 18. Abdullah now works for a program that helps foster children with the transition to independence.

"I was labeled unadoptable at 5 years old," Abdullah said. "I shouldn't have had to go through what I went through."

\section{A tale of two grandmothers}

Belinda Jackson and Jackie Hardy have 22 grandchildren between them, and it has not been easy.

As they tell it, their family lives are tangled webs of social workers, foster care, health problems, homelessness, courts, lawyers, prison, drugs, welfare, abuse and estrangement.

These women - new friends who met through the Greater Sacramento Grandparents Network and attended the recent conference in Sacramento - seem surprisingly optimistic, considering their situations.

But they have horror stories to share about their experiences with "the system," the often bewildering morass of courts and government agencies that control who their grandchildren live with and where.

"They don't give you a book" on how to deal with it, Jackson says.

At age 46, Jackson has 11 grandchildren, all by one daughter with bipolar disorder, who has been institutionalized several times. The grandchildren range from 13 years old to 2 -year-old triplets; two more children died. "Every year, my daughter had a baby," Jackson says.

Jackson was granted guardianship or custody of most of the grandchildren several years ago (four now live in Louisiana), but they were removed by the sys-

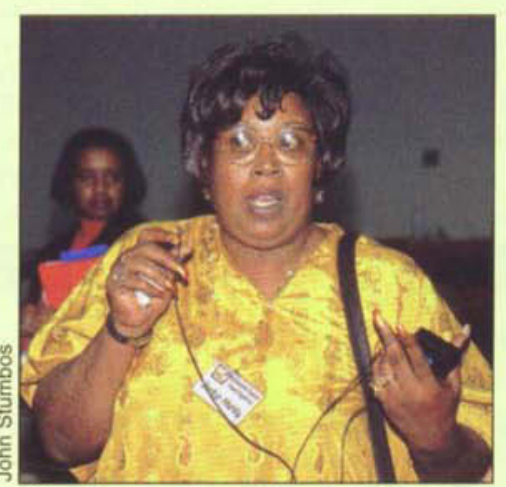

"I've been advocating for 10 years for my grandchildren," Jackie Hardy, grandmother of 11 , said at a Sacramento conference.
"As I write, my grandkids are going through hell in the foster homes they are in," Jackson put down in a letter addressed to whoever will take it. "My grandkids are afraid of losing me as they have been put in fear too many times with the system."

Hardy's situation is similarly wrenching. At 53, Hardy is currently taking care of two of her 11 grandchildren, and is trying to get three others out of foster care. "I've been advocating for 10 years for my grandchildren," she says.

One of Hardy's granddaughters, an 11-yearold, has lived in 16 foster homes so far. "The [courts] would tell me, 'You don't have any rights'," Hardy says. "The social workers blocked me. But I'm her grandmother. I'm not going anywhere."

Furthermore, the five grandchildren Hardy is trying to reunite have five different lawyers. "The courts don't want to hear anything I have to say," Hardy says. "It hurts. It does hurt."

The stress on the grandchiltem after she was forced to leave the house where they were living.

"They have taken my whole life," Jackson says. "I have nothing but my heart, and Jesus. Thirteen years of my life I've been raising nothing but my grandchildren."

After taking court-ordered counseling and parenting classes, Jackson's main focus is now on finding a five-bedroom Section 8 house, not a simple task. dren, having to live apart from family members who care about them, is unfathomable to Hardy. "It's hard on those kids. They don't get to see each other ... I constantly tell the kids, 'You did not do anything wrong'."

"The kids all worry," Jackson adds. "I have to hear them say, 'Grandma, I want to come home.' I'm afraid for them. I don't want someone else to raise them."

$$
-J \cdot B \text {. }
$$

